\title{
Predation mortality of bay anchovy Anchoa mitchilli eggs and larvae due to scyphomedusae and ctenophores in Chesapeake Bay
}

\author{
Jennifer E. Purcell ${ }^{1}$, David A. Nemazie ${ }^{1}$, Suzanne E. Dorsey ${ }^{2, *}$, Edward D. Houde ${ }^{2}$, \\ John C. Gamble ${ }^{3, * *}$ \\ ${ }^{1}$ University of Maryland System, Center for Environmental and Estuarine Studies (UMCEES), Horn Point Environmental \\ Laboratory, PO Box 775, Cambridge, Maryland 21613, USA \\ ${ }^{2}$ UMCEES, Chesapeake Biological Laboratory, PO Box 38, Solomons, Maryland 20688, USA \\ ${ }^{3}$ Sir Alister Hardy Foundation for Ocean Science, Prospect Place, Plymouth PL1 3DH, United Kingdom
}

\begin{abstract}
We measured predation on bay anchovy Anchoa mitchilli eggs and larvae by abundant scyphomedusae Chrysaora quinquecirha and ctenophores Mnemiopsis leidyi from gut contents, digestion rates, and densities of predators and prey during $9 \mathrm{~d}$ in July 1991 at 4 stations in Chesapeake Bay, USA. These predation rates were compared to egg and larval mortality rates measured concurrently in ichthyoplankton surveys. Daily predation by medusae and ctenophores was $19 \pm 13 \%$ (mean $\pm \mathrm{SD}$ ) of the eggs over the $20 \mathrm{~h}$ stage duration, with medusae responsible for 26 to $100 \%$ of the predation. These gelatinous predators accounted for $21 \pm 17 \%$ of the total estimated daily egg-stage mortality. On average, medusae consumed $29 \pm 14 \% \mathrm{~d}^{-1}$ of the larval bay anchovy, which was $41 \pm 35 \%$ of total estimated larval mortality. Predation on larvae by ctenophores was not detected. These predation effects are compared with those measured concurrently in free-drifting $3.2 \mathrm{~m}^{3}$ mesocosms. We conclude that medusae, which had high feeding rates but low abundances, and ctenophores, which had low feeding rates but high abundances, were important predators of bay anchovy eggs and larvae in the mesohaline region of Chesapeake Bay.
\end{abstract}

KEY WORDS: Anchoa - Chrysaora - Mnemiopsis - Fish eggs · Fish larvae Scyphomedusae $\cdot$ Ctenophores - Predation - Mortality · Feeding · Chesapeake Bay

\section{INTRODUCTION}

Gelatinous zooplankton often prey upon the early life stages of fishes (reviewed in Alvarino 1985, Purcell 1985, Arai 1988, Bailey \& Houde 1989). Typically, fish eggs and larvae are incidental prey of several pelagic hydrozoans, scyphozoans, and ctenophores (see above reviews). For example, fish eggs were 0.1 and $0.4 \%$ of the prey items in the scyphomedusan Stomolophus meleagris (Larson 1991) and the ctenophore Mnemiopsis leidyi (Burrell \& Van Engel 1976), respectively. However, fish eggs and larvae can be a large fraction

\footnotetext{
- Present address: Marine Sciences Research Center, State University of New York at Stony Brook, Stony Brook, New York 11794-5000, USA

$\because$ Died on August 10, 1994
}

of the prey items of some gelatinous zooplankton species. Fish eggs were numerous prey of some scyphomedusae - Cyanea capillata (1.6 to $62.9 \%$ ) and Pseudorhiza haeckeli (2.0 to 69.5\%; Fancett 1988). Fish larvae were 94 to $100 \%$ of the prey of cystonect siphonophores, which consumed 28 to $60 \% \mathrm{~d}^{-1}$ of the larvae present (Purcell 1981, 1984). The hydromedusan Aequorea victoria ate mostly herring larvae at peak hatching ( 48 to $100 \%$ of the prey), and consumed as much as $97 \% \mathrm{~d}^{-1}$ of the larvae (Purcell 1989, Purcell $\&$ Grover 1990). Although the rates of predation on ichthyoplankton have been quantified occasionally, the predation rates have never been compared to mortality rates in situ.

Gelatinous zooplankton, mainly the ctenophore Mnemiopsis leidyi and the scyphozoan Chrysaora quinquecirrha, are seasonally abundant in the meso- 
Table 1. Sampling dates, locations, maximum sampling depths, and dissolved oxygen concentrations above and below the pycnocline in Chesapeake Bay during July 1991. Depths of the top of the pycnocline are in parentheses

\begin{tabular}{|c|c|c|c|c|c|}
\hline \multirow[t]{2}{*}{ Date } & \multirow[t]{2}{*}{ Stn } & \multirow[t]{2}{*}{ Location } & \multirow{2}{*}{$\begin{array}{l}\text { Depth } \\
(\mathrm{m})\end{array}$} & \multicolumn{2}{|c|}{ Dissolved oxygen (ppm) } \\
\hline & & & & Above & Below \\
\hline $7-8$ July & 4 & $37^{\circ} 56-59^{\prime} \mathrm{N}, 76^{\circ} 10-14^{\prime} \mathrm{W}$ & $16(8-10)$ & $2.8-8.2$ & $0.8-4.4$ \\
\hline 18 July & 7 & $38^{\circ} 23-26^{\prime} \mathrm{N}, 76^{\circ} 21-22^{\prime} \mathrm{W}$ & $21(10)$ & $3.1-7.4$ & $0.1-4.9$ \\
\hline 19 July & 6 & $38^{\circ} 16-20^{\prime} \mathrm{N}, 76^{\circ} 17-18^{\prime} \mathrm{W}$ & $23(11)$ & $6.3-7.5$ & $0.1-6.3$ \\
\hline 20-24 July & 5 & $38^{\circ} 04-09^{\prime} \mathrm{N}, 76^{\circ} 11-15^{\prime} \mathrm{W}$ & $27(12)$ & $3.2-7.0$ & $0.3-5.6$ \\
\hline
\end{tabular}

haline region of Chesapeake Bay, USA, reaching maximum biomass in July and August (Purcell et al. 1994). Both gelatinous species are believed to be important components of the pelagic food web in Chesapeake Bay (Feigenbaum \& Kelly 1984, Baird \& Ulanowicz 1989). Their main prey are crustacean zooplankton, mostly the copepod species Acartia tonsa (Burrell \& Van Engel 1976, Purcell 1992). They were estimated to consume up to $13 \% \mathrm{~d}^{-1}$ of the copepod production in the mesohaline region of the bay (Purcell et al. 1994).

Bay anchovy Anchoa mitchilli is the most abundant fish species in estuaries of the U.S. Atlantic coast (Houde \& Zastrow 1991). Spawning occurs throughout most of Chesapeake Bay, in salinities from $<5$ to $>23 \%$ (Dovel 1971, Olney 1983), and takes place nightly (Luo \& Musick 1991, Zastrow et al. 1991). In Chesapeake Bay, spawning occurs at low levels from May to September, with a strong peak in July (Dalton 1987). At temperatures $\geq 26^{\circ} \mathrm{C}$, the eggs hatch in 20 to $24 \mathrm{~h}$ (Houde \& Zastrow 1991).

Because both bay anchovy spawning and gelatinous zooplankton biomass peak in July in mid Chesapeake Bay, predation by the gelatinous species may be a major cause of egg and larval mortality (Cowan \& Houde 1993). Herein, we estimate daily predation rates on bay anchovy eggs and larvae from medusa and ctenophore gut contents, digestion rates, and the abundances of the predators and prey. We compare these predation estimates with in situ mortality rates estimated concurrently by the decreases in numbers of eggs and larvae in the plankton over $24 \mathrm{~h}$ periods (Dorsey 1993). We also compare cur results with those from free-drifting $3.2 \mathrm{~m}^{3}$ mesocosms that were deployed daily (Houde et al. in press) .

\section{MATERIALS AND METHODS}

Sampling dates and locations. Seven stations in Chesapeake Bay were sampled in July 1991 (Table 1, Fig 1) Because no gelatinous predators were found at Stns 1 to 3 , the following analyses refer only to Stns 4 to 7 in the mesohaline region of Chesapeake Bay (Fig. 1). Sampling for zooplankton was conducted every 6 to
$8 \mathrm{~h}$, and for ichthyoplankton every $2 \mathrm{~h}$, over $24 \mathrm{~h}$ on 9 dates at Stns 4 to 7 . The specific location of each sampling effort was determined by the location of freedrifting in situ mesocosms, which were assumed to track the water mass in which they were deployed. Deployments were made near midnight on each night (Houde et al. in press). Temperature, salinity and oxygen profiles were made periodically each day with a CTD. Temperature of the surface waters was 25 to $28^{\circ} \mathrm{C}$ at the 4 stations. The bottom waters had reduced levels of oxygen during this study (Table 1), as is typical of the mesohaline portion of the bay during summer. Therefore, results are reported only for waters above the pycnocline, unless otherwise indicated.

Gelatinous zooplankton biovolumes, densities, and sizes. Medusae Chrysaora quinquecirrha and ctenophores Mnemiopsis leidyi were collected in 2 nets with flowmeters, and the mean densities calculated. First, a

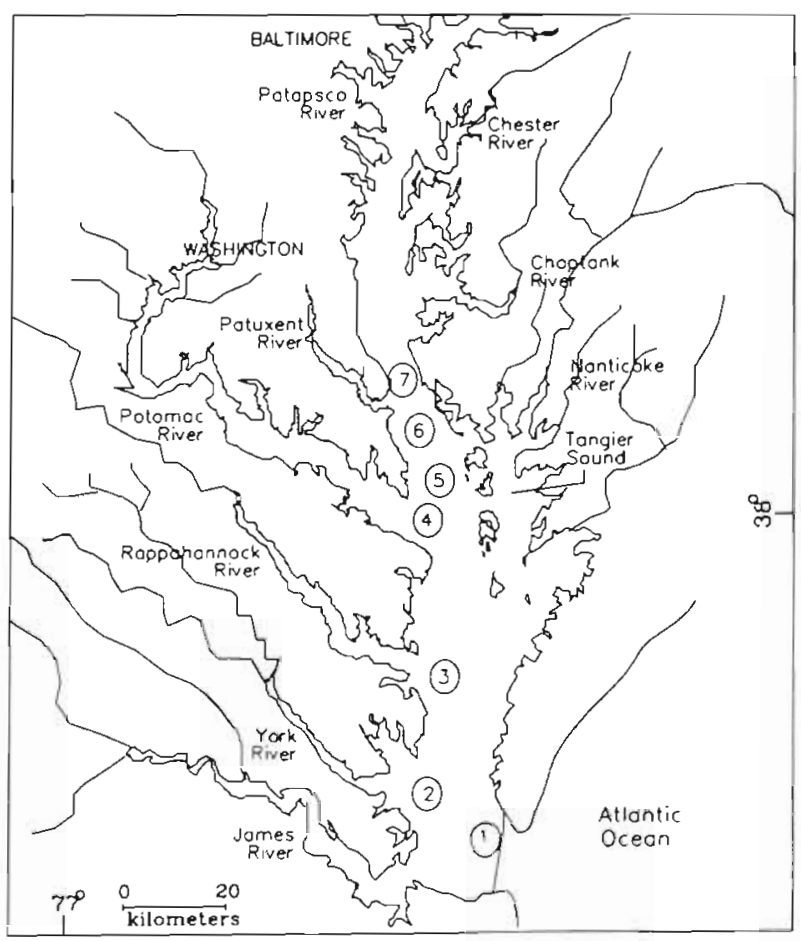

Fig. 1. Sampling stations in Chesapeake Bay during July 1991 
$1 \mathrm{~m}$ diameter, $1.6 \mathrm{~mm}$ mesh plankton net was towed obliquely from the surface to the pycnocline or near bottom, and back. Second, a $0.6 \mathrm{~m}$ diameter net with $280 \mu \mathrm{m}$ mesh was opened near bottom and towed obliquely to the pycnocline and closed; on a second deployment, it was opened at the pycnocline and then towed to the surface. Volumes of water filtered ranged from 13 to $107 \mathrm{~m}^{3}$, but most tows filtered 30 to $50 \mathrm{~m}^{3}$ Each sample was poured through a sieve to retain the gelatinous plankton, then total live volume for each gelatinous species was measured in graduated cylinders. All specimens from most tows were measured immediately to the nearest $\mathrm{mm}$ (medusa diameter, ctenophore length). A few samples were preserved (final concentration 5\% formalin). All specimens in those samples were counted and measured later in the laboratory and live sizes calculated as in Purcell (1988, 1992).

Bay anchovy egg and larva densities, and mortality rates. Two collections were made every $2 \mathrm{~h}$ with a $0.4 \mathrm{~m}$ diameter plankton net with bridle and $280 \mu \mathrm{m}$ mesh. The net was lifted vertically from near bottom to the surface. Flowmeter readings indicated that $3.0 \pm$ $1.4 \mathrm{~m}^{3}$ of water was filtered in each tow (Dorsey 1993), and samples typically contained hundreds of eggs and 10 to 100 larvae. Samples were preserved in 5\% formalin. Eggs and larvae were counted in the laboratory, and larval numbers corrected for net extrusion (Dorsey 1993, McGregor 1994). Instantaneous mortality rates of eggs and yolk-sac larvae were estimated from the exponential model $N_{t}=N_{0} \mathrm{e}^{-Z t}$, where $N_{t}=$ cohort abundance (no. $\mathrm{m}^{-2}$ ) at age $t, N_{0}=$ cohort initial abundance (no. $\mathrm{m}^{-2}$ ), $Z$ = instantaneous mortality coefficient $\left(\mathrm{h}^{-1}\right), t=$ age $(\mathrm{h})$, as in Dorsey (1993)

Zooplankton densities. Crustacean zooplankton was collected adjacent to the drifting mesocosms with a diaphragm pump by filtering $50 \mathrm{l}$ through a $35 \mathrm{\mu m}$ mesh net. Each sample was integrated from near bottom to surface by pumping at 2 to $3 \mathrm{~m}$ depth intervals. In the laboratory, preserved samples ( $5 \%$ formalin) were brought to $50 \mathrm{ml}$ volume. Then zooplankton was counted from three $1 \mathrm{ml}$ aliquots, identified to order, and the mean number per liter calculated.

Gelatinous zooplankton gut content analyses. At the times of net sampling, medusae and ctenophores were collected individually by dip net and immediately preserved in $5 \%$ formalin for gut content analysis. In the laboratory, predator sizes were measured as above, and fish eggs and larvae that had been eaten were counted using a dissecting microscope. For some medusa gut samples, all prey, including zooplankton, were counted. For these samples, electivity indices $(C)$ were calculated from the numbers of prey $\mathrm{m}^{-3}$ (from corresponding zooplankton samples) and the numbers of each prey type in the gut contents, and the signifi- cance tested (chi squared) according to Pearre (1982). We did not quantify all prey of Mnemiopsis leidyi in the present study, and so we were unable to evaluate selection on fish eggs or larvae.

Digestion times. Freshly collected medusae were put in 201 containers overnight to clear their guts. Then bay anchovy eggs were added, and the medusae allowed to feed for $<10 \mathrm{~min}$ until several eggs had been ingested. Each medusa was transferred to a 41 container with filtered water $\left(12 \%\right.$ salinity, $\left.26 \pm 1{ }^{\circ} \mathrm{C}\right)$, and the eggs in the gastric pouches counted using a dissecting microscope. The numbers of eggs were counted at 30 min intervals until none were seen. The periods of time between ingestion and when each egg disappeared were averaged to estimate digestion time for every medusa. Medusa diameter was measured after the experiment. The relationship of digestion time to medusa diameter and the number of eggs ingested was tested in a stepwise multiple regression. The same methods were used to determine digestion times of newly hatched bay anchovy larvae, except that the larvae were observed in the medusae at 15 min intervals.

Freshly collected ctenophores with empty guts were allowed to feed on bay anchovy eggs in 41 containers for $<10 \mathrm{~min}$, and then were transferred to $100 \mathrm{ml}$ dishes of filtered water ( $14 \%$ salinity, $24 \pm 1^{\circ} \mathrm{C}$ ). The eggs in the stomodeum were counted and observed using a dissecting microscope at 10 to 15 min intervals until they could not be recognized as eggs. Ctenophore length was measured with a ruler, and then they were preserved in $5 \%$ formalin to determine if the egg remains could be recognized in the gut contents.

Feeding rates and predation effects. Multiple regression analyses were performed to relate the numbers of eggs and larvae found in medusa gut contents to egg or larval densities, and to medusa size. We did not include time of day because egg and larval densities were correlated with the time of day (Dorsey 1993). We then used the regression equations to predict the numbers of eggs and larvae in medusae from data on egg and larval densities and mean medusa diameter at each sampling time. We used this approach rather than using the gut content data directly to calculate predation because gut analyses were lacking for some sampling times, and because the mean sizes of dipped medusae were greater than sizes in plankton tows. Thus, for each sampling time, feeding rates of medusae on bay anchovy eggs were calculated according to the following equation. $I=G / D \times P$, where $I=$ number of fish eggs ingested $\mathrm{m}^{-3} \mathrm{~h}^{-1}, G=$ number of fish eggs in each medusa from the regression), $D=$ digestion time in hours, and $P=$ number of predators $\mathrm{m}^{-3}$. Then, to estimate the proportion consumed, I was divided by the estimated mean number 
of fish eggs $\mathrm{m}^{-3}$ in the preceding $4 \mathrm{~h}$ (due to the $4 \mathrm{~h}$ digestion time), plus the numbers of eggs inside the medusae in $1 \mathrm{~m}^{3}$. The same calculations were made for fish larvae, using larval densities in the immediately preceding plankton sample (due to the $1 \mathrm{~h}$ digestion time). The proportions of eggs and larvae eaten $\mathrm{h}^{-1}$ by medusae were converted to instantaneous mortality rates, averaged, and multiplied by $20 \mathrm{~h}$ for eggs and $24 \mathrm{~h}$ for larvae to give daily rates $\left(Z_{\mathrm{EM}} 20 \mathrm{~h}^{-1}\right.$ and $Z_{\mathrm{LM}}$ $\mathrm{d}^{-\mathrm{t}}$, respectively). $Z_{\mathrm{LM}} \mathrm{d}^{-1}$ were compared with total estimated yolk-sac larval mortality rates $\left(Z_{L T}\right)$ from Dorsey (1993).

Hourly egg ingestion rates due to ctenophores were calculated for each sampling time with the above equation for $I$, using the actual numbers of eggs in the ctenophore gut contents, 35 min digestion time, and the densities of ctenophores and eggs in the immediately preceding plankton samples. Hourly ingestion. rates were converted to egg mortality rates due to ctenophores over the $20 \mathrm{~h}$ egg stage $\left(Z_{\mathrm{EC}} 20 \mathrm{~h}^{-1}\right)$. The combined egg mortality due to medusae and ctenophores $\left(Z_{\mathrm{EP}} 20 \mathrm{~h}^{-1}\right)$ was obtained by adding $Z_{\mathrm{EM}} 20 \mathrm{~h}^{-1}$ to $Z_{\mathrm{EC}} 20 \mathrm{~h}^{-1}$, and was compared with total estimated egg mortality rates $\left(Z_{\mathrm{ET}}\right)$ from Dorsey (1993).

\section{RESULTS}

\section{Gelatinous zooplankton biovolumes, densities, and sizes}

Comparisons of medusa and ctenophore biovolumes in paired samples above and below the pycnocline showed that both species had higher biovolumes in the surface waters during both day and night (Table 2). Two-way analysis of variance showed that the effects of depth were significant (for medusae $F=4.44, \mathrm{p}<$ 0.05; for ctenophores $F=7.60, \mathrm{p}<0.01$ ), but neither time nor the interaction between time and depth was significant. Therefore, our results show no clear indication of diel vertical migration for either species. Dissolved oxygen levels below the pycnocline ranged

Table 2. Chrysaora quinquecirrha and Mnemiopsis leidyi Biovolume $\left(\mathrm{ml} \mathrm{m}^{-3}\right)$ above and below the pycnocline during day and night. The numbers of tows are in parentheses

\begin{tabular}{|c|c|c|}
\hline Species and depth & Day & Night \\
\hline \multicolumn{3}{|l|}{ C. quinquecirrha } \\
\hline Above & $4.0 \pm 0.9$ & $5.9 \pm 102(15)$ \\
\hline Below & $3.3 \pm 8.8 \quad(12)$ & $1.9 \pm 3.2$ \\
\hline \multicolumn{3}{|l|}{ M. leıdyi } \\
\hline Above & $29.6 \pm 27.4(13)$ & $29.2 \pm 30.4(14)$ \\
\hline Below & $10.6 \pm 15.9(13)$ & $13.1 \pm 15.7(14)$ \\
\hline
\end{tabular}

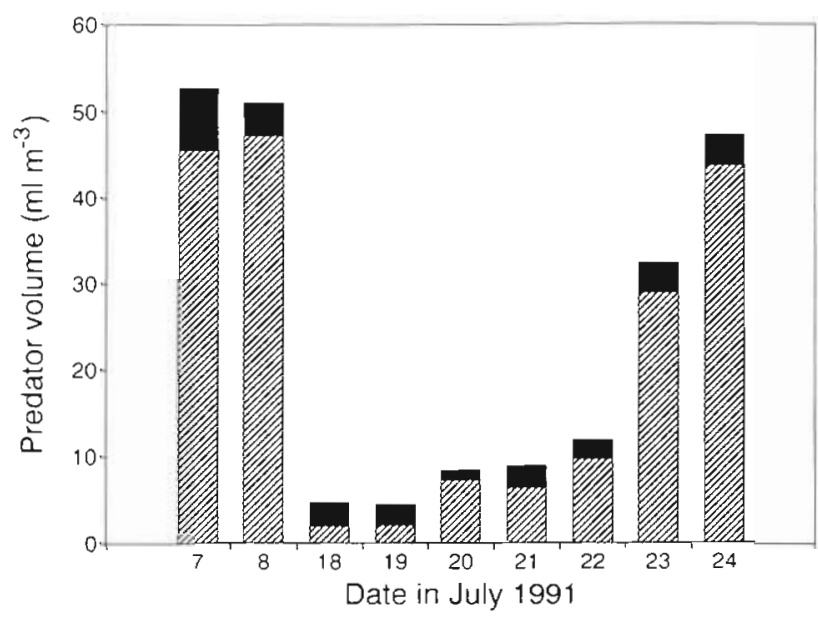

Fig. 2. Chrysaora quinquecirrha and Mnemiopsis leidyi. Mean live biovolume of medusae (solid bars) and ctenophores (hatched bars) on each sampling date in July 1991. Values shown are means from $16 \pm 3$ tows on each day

from hypoxic $(<2 \mathrm{ppm})$ to well oxygenated (Table 1$)$. Some of the deeper hypoxic waters might have excluded the gelatinous species, but our sampling could not resolve the fine-scale vertical distributions. Further analyses were restricted to the surface waters above the pycnocline.

Biovolumes of combined predator species were greatest on 7-8 July (Stn 4), and 23-24 July (Stn 5) (Fig. 2). Ctenophores had much greater biovolumes than medusae on all dates except 18 and 19 July (Stns 7 and 6), when their combined biovolumes were lower than on other dates (Fig. 2). Medusa densities usually were $\leq 0.2 \mathrm{~m}^{-3}$ (Table 3 ), but were as high as $0.8 \mathrm{~m}^{-3}$. In addition to having greater biovolumes, ctenophores were more numerous than medusae (Table 3), reaching densities up to $5 \mathrm{~m}^{-3}$.

The mean sizes of medusae and ctenophores in the plankton samples were less than those collected for gut content analyses (Tables 3 \& 4). Mean medusa sizes in the plankton ranged from 31 to $52 \mathrm{~mm}$ in preserved diameter, while gut content specimens averaged 45 to $7.3 \mathrm{~mm}$. Paired means for each sampling time were significantly different between towed and dipped medusae $(p<0.001$. Wilcoxin Signed Rank Test, $\mathrm{n}=24$ ). Because size strongly affects feeding rates of medusae (Purcell 1992), we used mean medusa sizes from the plankton tows in regression equations to calculate predation by medusae. Mean ctenophore weights in the plankton tows ranged from 22 to $47 \mathrm{~g}$ wet weight, while those collected for gut contents ranged from 11 to $56 \mathrm{~g}$ (Tables $3 \& 4$ ). The mean sizes in paired samples were not significantly different $(p=0.09$, Wilcoxin Signed Rank Test, $n=7$ ), therefore no adjustments were made to the ctenophore predation rates. 
Table 3. Densities of medusae and ctenophores and their sizes, and bay anchovy egg and yolk-sac larval densities from plankton tows in July 1991. The numbers of tows are for predators, eggs, and larvae, respectively. The egg and larval densities are means of those used in predation analyses, not from all 24 tows made daily. Values are means \pm 1 SD. The numbers of predators measured for size [preserved medusa diameter and ctenophore wet weight (calculated from equation in Purcell 1988)] are in parentheses. na: not available

\begin{tabular}{|c|c|c|c|c|c|c|c|c|c|}
\hline $\begin{array}{l}\text { Date } \\
\text { (1991) }\end{array}$ & Stn & $\begin{array}{c}\text { Samples } \\
d^{-1}\end{array}$ & $\begin{array}{l}\text { No. of } \\
\text { tows }\end{array}$ & $\begin{array}{l}\text { Medusae } \\
\left(\text { no. } \mathrm{m}^{-3} \text { ) }\right.\end{array}$ & $\begin{array}{l}\text { Medusa } \\
\text { size }(\mathrm{mm})\end{array}$ & $\begin{array}{c}\text { Ctenophores } \\
\left(\text { no. } \mathrm{m}^{3} \text { ) }\right.\end{array}$ & $\begin{array}{c}\text { Ctenophore } \\
\text { sire (g) }\end{array}$ & $\begin{array}{c}\text { Eggs } \\
\left(\text { no. } \mathrm{m}^{-3}\right)\end{array}$ & $\begin{array}{c}\text { Larvae } \\
\left(\text { no. } \mathrm{m}^{-3}\right)\end{array}$ \\
\hline $7 \mathrm{Jul}$ & 4 & 4 & $10,24,8$ & $0.2 \pm 0.1$ & $31.2 \pm 25.1(32)$ & $2.9 \pm 1.6$ & $23.7 \pm 9.7(56)$ & $62.3 \pm 56.5$ & $14.0 \pm 14.1$ \\
\hline $8 \mathrm{Jul}$ & 4 & 3 & $8,18,6$ & $0.2 \pm 0.1$ & $35.4 \pm 30.3(39)$ & $2.9 \pm 0.7$ & $22.4 \pm 9.5(94)$ & $63.8 \pm 35.2$ & $6.2 \pm 3.5$ \\
\hline $18 \mathrm{Jul}$ & 7 & 4 & $12,23,8$ & $0.2 \pm 0.2$ & $34.8 \pm 36.0(137)$ & $0.1 \pm 0.03$ & na & $358.3 \pm 280.0$ & $77.8 \pm 58.1$ \\
\hline $19 \mathrm{Jul}$ & 6 & 4 & $14,20,8$ & $0.2 \pm 0.2$ & $37.9 \pm 17.1(106)$ & $0.1 \pm 0.06$ & nà & $288.7 \pm 169.8$ & $69.7 \pm 52.8$ \\
\hline $20 \mathrm{Jul}$ & 5 & 4 & $15,22,8$ & $0.06 \pm 0.04$ & $52.3 \pm 19.2(42)$ & $0.3 \pm 0.3$ & na & $219.0 \pm 102.8$ & $64.3 \pm 54.2$ \\
\hline $21 \mathrm{Jul}$ & 5 & 3 & $11,18,6$ & $0.1 \pm 0.03$ & $50.8 \pm 26.1(31)$ & $0.2 \pm 0.1$ & $47.4 \pm 13.9(21)$ & $229.0 \pm 216.2$ & $25.4 \pm 13.8$ \\
\hline 22 Jul & 5 & 4 & $12,24,8$ & $0.1 \pm 0.04$ & $38.4 \pm 19.7(56)$ & $0.4 \pm 0.7$ & $40.4 \pm 11.3(27)$ & $55.1 \pm 48.8$ & $60.2 \pm 89.1$ \\
\hline $23 \mathrm{Jul}$ & 5 & 4 & $12,24,8$ & $0.1 \pm 0.1$ & $38.1 \pm 21.6(33)$ & $1.3 \pm 0.6$ & $37.9 \pm 10.3(31)$ & $128.8 \pm 91.0$ & $32.9 \pm 13.4$ \\
\hline $24 \mathrm{Jul}$ & 5 & 4 & $9,22,8$ & $0.1 \pm 0.06$ & $43.0 \pm 17.0(31)$ & $2.1 \pm 0.4$ & $27.0 \pm 13.8(66)$ & $60.7 \pm 104.5$ & $32.6 \pm 40.1$ \\
\hline
\end{tabular}

Table 4. Numbers of bay anchovy eggs and larvae found in the gut contents of medusae and ctenophores, and the sizes (as in Table 3) of predators dipped from surface waters in July 1991. Numbers of predators are for medusae, and ctenophores, respectively. Values are means $\pm 1 \mathrm{SD}$

\begin{tabular}{|ccccccccc|}
\hline $\begin{array}{l}\text { Date } \\
\text { (1991) }\end{array}$ & Str & $\begin{array}{c}\text { Samples } \\
\mathrm{d}^{-1}\end{array}$ & $\begin{array}{c}\text { No. of } \\
\text { predators }\end{array}$ & $\begin{array}{c}\text { No. eggs } \\
\text { medusa }^{-1}\end{array}$ & $\begin{array}{c}\text { No. larvae } \\
\text { medusa }\end{array}$ & $\begin{array}{c}\text { Medusa } \\
\text { size (mm) }\end{array}$ & $\begin{array}{c}\text { No. eggs } \\
\text { ctenophore }\end{array}$ & $\begin{array}{c}\text { Ctenophore } \\
\text { size (g) }\end{array}$ \\
\hline 7 Jul & 4 & 2 & 6,16 & $32.0 \pm 25.9$ & $1.7 \pm 2.7$ & $53.2 \pm 14.9$ & $0.2 \pm 0.4$ & $25.2 \pm 13.9$ \\
$8 \mathrm{Jul}$ & 4 & 4 & 6,10 & $23.7 \pm 29.5$ & $0.2 \pm 0.4$ & $49.8 \pm 22.5$ & $0.5 \pm 0.5$ & $23.6 \pm 11.5$ \\
$18 \mathrm{Jul}$ & 7 & 3 & 30,7 & $91.6 \pm 96.0$ & $4.9 \pm 4.4$ & $46.7 \pm 16.0$ & $0.3 \pm 0.5$ & $48.4 \pm 17.7$ \\
19 Jul & 6 & 3 & 22,0 & $134.8 \pm 160.9$ & $18.9 \pm 25.4$ & $60.3 \pm 16.4$ & - & - \\
$20 \mathrm{Jul}$ & 5 & 2 & 7,13 & $27.9 \pm 47.6$ & $0.6 \pm 0.5$ & $72.7 \pm 27.2$ & $0.8 \pm 0.9$ & $62.8 \pm 15.8$ \\
21 Jul & 5 & 3 & 13,1 & $261.8 \pm 420.6$ & $12.9 \pm 22.0$ & $59.2 \pm 16.5$ & 3.0 & 55.7 \\
22 Jul & 5 & 4 & 15,3 & $32.0 \pm 32.2$ & $0.5 \pm 1.0$ & $48.7 \pm 16.3$ & $0.7 \pm 0.6$ & $49.6 \pm 21.5$ \\
23 Jul & 5 & 2 & 6,10 & $66.0 \pm 116.2$ & 0 & $45.3 \pm 17.9$ & $0.3 \pm 0.5$ & $44.8 \pm 10.0$ \\
24 Jul & 5 & 3 & 12,15 & $7.6 \pm 14.6$ & $2.8 \pm 3.5$ & $57.9 \pm 16.5$ & 0 & $54.7 \pm 10.5$ \\
\hline
\end{tabular}

\section{Diet and prey selection of medusae}

All prey were counted from 80 medusae. Bay anchovy eggs represented from 0.1 to $90.1 \%$ (mean $21.4 \pm 23.5 \%$ ) of the total prey items in each gut sample. Bay anchovy larvae were less numerous in medusa gut contents, accounting for 0 to $8.8 \%$ of the prey (mean $1.3 \pm 2.6 \%$ ). Eggs, larvae, copepods, and cladocerans together were $95 \%$ of the total prey. Selection was positive and significant for eggs in 10 of 12 samples, for larvae in 9 of 12 samples, for copepods in 10 of 12 samples, and for cladocerans in all samples (examples in Table 5). Fish eggs were about as numerous in the diet as were copepods, even though copepods in situ were 400 times more abundant than eggs (Table 5). No significant negative selection was found for fish eggs or larvae in any samples.

\section{Digestion times}

The mean digestion time of bay anchovy eggs by 16 medusae at $26^{\circ} \mathrm{C}$ was $3.9 \pm 0.8 \mathrm{~h}$. Digestion times $(3.7$ to $5.2 \mathrm{~h}$ ) were not significantly related to medusa size (23 to $44 \mathrm{~mm}$ live diameter, $\mathrm{p}=0.1$ ) or to the number

Table 5. Chrysaora quinquecirrha. Bay anchovy eggs, larvae and major zooplankton taxa in the diet of medusae and in situ in 1991, and indices of prey selection $(C)$ according to Pearre (1982). $n=8$ and 6 medusae. $" p<0.005$

\begin{tabular}{|c|c|c|c|c|c|}
\hline & $\begin{array}{l}\text { Fish } \\
\text { eggs }\end{array}$ & $\begin{array}{l}\text { Fish } \\
\text { larvae }\end{array}$ & Copepods & $\begin{array}{r}\text { Cladocerans } \\
\text { zo }\end{array}$ & $\begin{array}{l}\text { Other } \\
\text { oplankton }\end{array}$ \\
\hline \multicolumn{6}{|l|}{18 July 04:00 h } \\
\hline No. prey medusa ${ }^{-1}$ & 199.4 & 4.6 & 187.2 & 13.1 & 1.5 \\
\hline No. prey $\mathrm{l}^{-1}$ & 0.39 & 0.16 & 61.0 & 2.7 & 71.1 \\
\hline$C$ & $0.621^{\circ}$ & $0.040^{\circ}$ & 0.004 & $0.014^{\circ}$ & - \\
\hline \multicolumn{6}{|l|}{19 July 22:00 h } \\
\hline No. prey medusa ${ }^{-1}$ & 189.1 & 45.0 & 279.6 & 61.6 & 4.1 \\
\hline No prey $1^{-1}$ & 0.12 & 0.04 & 25.3 & 4.0 & 30.0 \\
\hline$C$ & $0.531^{\circ}$ & $0.252^{\circ}$ & $0.028^{\circ}$ & $0.037^{\circ}$ & - \\
\hline
\end{tabular}


of eggs ingested ( 9 to 52 eggs medusa ${ }^{-1}, p=0.2$ ). The mean digestion time of 1 to 9 bay anchovy larvae by 7 medusae was $1.1 \pm 0.5 \mathrm{~h}$. Therefore, $4 \mathrm{~h}$ and $1 \mathrm{~h}$ were used as the digestion times for eggs and larvae, respectively, in feeding rate calculations for medusae.

Large ctenophores (50 to $75 \mathrm{~mm}$ live length) digested 1 or 2 eggs in $37.4 \pm 8.7$ min ( $n=20$ eggs). Egg remains were found in the preserved specimens after $30 \mathrm{~min}$ digestion, but not after $40 \mathrm{~min}$. Small ctenophores $(7$ to $22 \mathrm{~mm}$ ) digested 1 or 2 eggs in $59.2 \pm 23.6 \mathrm{~min}(\mathrm{n}=13$ eggs). Because ctenophores during the field sampling were large ( 40 to $130 \mathrm{~mm}$ ), we use $35 \mathrm{~min}$ as the digestion time for eggs in feeding rate calculations for ctenophores.

\section{Feeding rates and predation effects}

Bay anchovy eggs and larvae were counted from the gut contents of 117 medusae. Table 4 gives daily
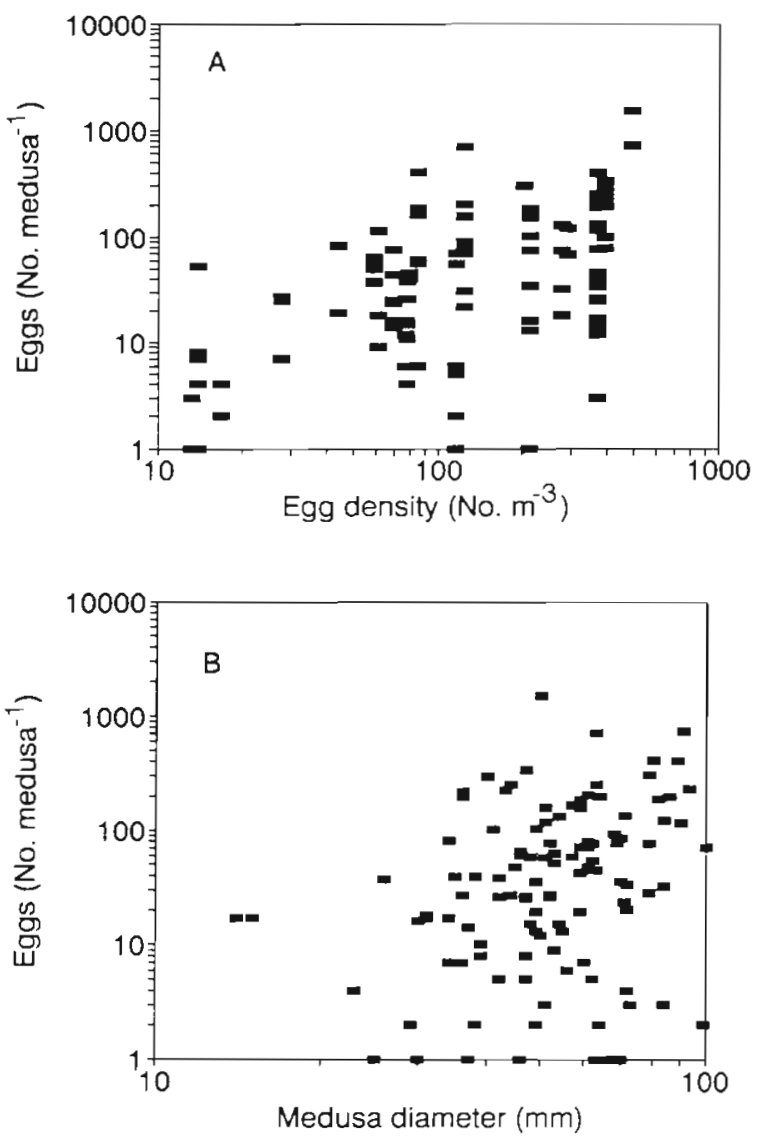

Fig. 3. Chrysaora quinquecirha. Numbers of bay anchovy eggs in medusa gut contents as related to (A) egg density (mean in preceding $4 \mathrm{~h}$ ) and ( $\mathrm{B}$ ) medusa diameter. One egg was added to each gut content value to allow the zero values to be included on the $\log _{10}$ scale. See Table 6 for the multiple regression analysis
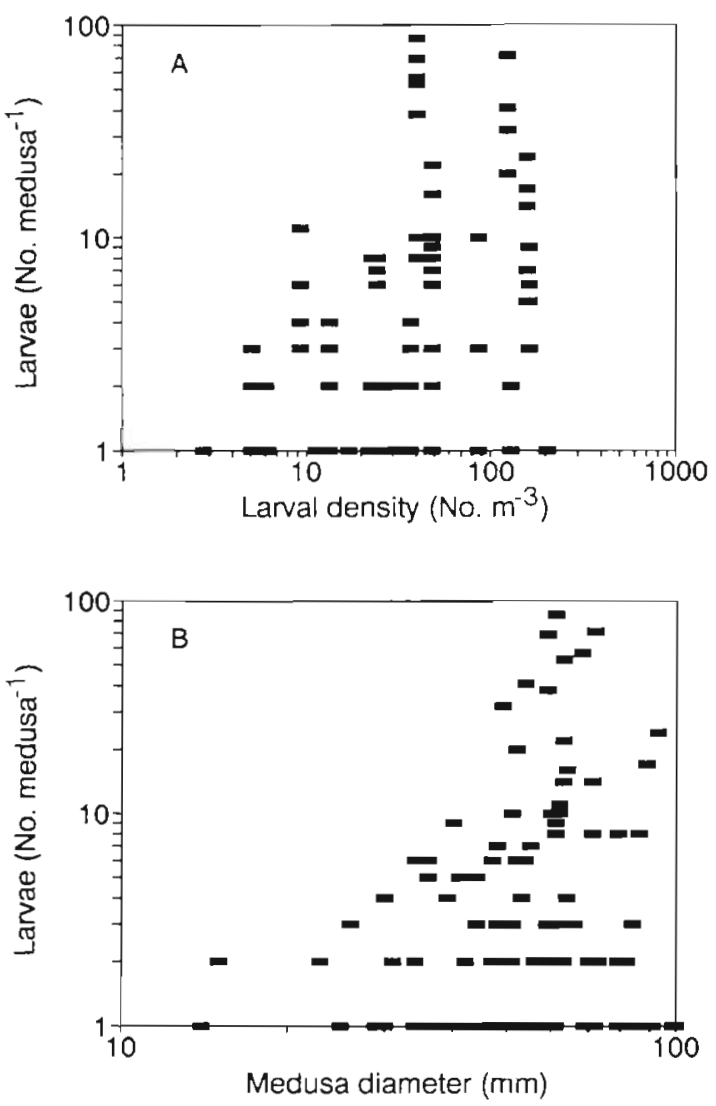

Fig. 4. Chrysaora quinquecirrha. Numbers of bay anchovy larvae in medusa gut contents as rclated to (A) larval density (mean in preceding $2 \mathrm{~h}$ ), and (B) medusa diameter. One larva was added to each gut content value to allow the zero values to be included on the $\log _{10}$ scale. See Table 7 for the multiple regression analysis

means of the numbers of eggs and larvae in medusa gut contents. Medusae contained from 0 to 1497 bay anchovy eggs. The number of eggs in each medusa was significantly and positively related to egg density (Fig. 3A), and to medusa size (Fig. 3B), which together explained $33.5 \%$ of the variation (Table 6 ).

Fewer larvae than eggs were found in medusa gut contents, with $34 \%$ containing no larvae. However, at 3 of the 24 sampling times unusually heavy predation on larvae had occurred. At those times, the mean numbers of larvae medusa ${ }^{-1}$ were: 19 July 09:00 h, $12.5 \pm$ $6.9(\mathrm{n}=6$ medusae); 19 July $21: 35 \mathrm{~h}, 44.9 \pm 29.2(\mathrm{n}=7)$; 21 July $01: 45 \mathrm{~h}, 40.2 \pm 22.2(\mathrm{n}=4)$. On 18 July, $4.9 \pm 4.4$ larvae were found in the medusa gut contents $(n=30)$, and at all other times, gut contents averaged $<2$ larvae per medusa. The number of larvae in each medusa was significantly and positively related to larval density (Fig 4A), and to medusa size (Fig. 4B), which together explained $22.6 \%$ of the variation (Table 7 ). 
Table 6. Chrysaora quinquecirrha. Multiple regression analysis of numbers of eggs in 117 medusae in relation to bay anchovy egg density (mean in 4 h period prior to collection of gut sample), and preserved medusa diameter. Regression equation: $\log Y=0.83 \log X_{1}+1.33 \log X_{2}-2.49 ;$ multiple $r^{2}=0.335 ;$ ANOVA $F$ $=26.96, p=3.3 \times 10^{-10} \cdot$ SE of estimate $=0.57$. 'Statistically significant

\begin{tabular}{|lccccc|}
\hline Variable & Range & Mean & Partial $\mathrm{r}^{2}$ & $F$ & $\mathrm{p}$ \\
\hline$X_{1}$, Eggs m $^{-3}$ & $13.2-492.3$ & 183.3 & 0.290 & 43.79 & $<1 \times 10^{-5} \cdot$ \\
$X_{2}$ Diameter $(\mathrm{mm})$ & $1.4-125$ & 55.3 & 0.117 & 14.14 & $<3 \times 10^{-4}$ \\
$Y_{\text {, Eggs medusa }}$. $^{-1}$ & $0-1497$ & 96.4 & - & - & - \\
\hline
\end{tabular}

Table 7. Chrysaora quinquecirrha. Multiple regression analysis of numbers of larvae in 117 medusae in relation to bay anchovy larva density (mean in $2 \mathrm{~h}$ period prior to collection of gut sample), and preserved medusa diameter. Regression equation: $\log Y=0.40 \log X_{1},+1.47 \log X_{2}-2.60 ;$ multiple $r^{2}=0.226$; ANOVA. $F=11.22, \mathrm{p}=5.3 \times 10^{-5} \cdot, \mathrm{SE}$ of estimate $=0.50$. 'Statistically significant

\begin{tabular}{|lccccc|}
\hline Variable & Range & Mean & Partial $^{2}$ & $F$ & $\mathrm{p}$ \\
\hline$X_{1}$, Larvae $\mathrm{m}^{-3}$ & $2.8-204$ & 42.0 & 0.122 & 10.66 & $<0.002$ \\
$X_{2}$, Diameter $(\mathrm{mm})$ & $14-125$ & 55.3 & 0.141 & 10.48 & $<0.002$ \\
$Y_{\text {. Larvae medusa }}{ }^{-1}$ & $0-71$ & 0.6 & - & - & - \\
\hline
\end{tabular}

Table 8. Anchoa mitchilli. Total egg mortality over the $20 \mathrm{~h}$ stage duration, eggs consumed by medusae and ctenophores, and the percentages of egg mortality that was due to the predators on sampling dates in July 1991 Total egg mortality calculated from Dorsey (1993). Percentages of $Z_{\mathrm{EP}}$ due to medusae are in parentheses

\begin{tabular}{|lccccc|}
\hline $\begin{array}{l}\text { Date } \\
\text { (1991) }\end{array}$ & \multicolumn{2}{c}{$\begin{array}{c}\text { Total egg mortality } \\
Z_{E T} 20 \mathrm{~h}^{-1}\end{array} \% 20 \mathrm{~h}^{-1}$} & \multicolumn{2}{c|}{ Eggs consumed } & Egg mortality due \\
\hline 7 Jul & 0.98 & 62.5 & $0.38(25.7)$ & 31.4 & 38.5 \\
8 Jul & 1.24 & 71.1 & $0.65(25.8)$ & 49.7 & 52.2 \\
18 Jul & 1.62 & 80.2 & $0.20(91.0)$ & 18.3 & 12.5 \\
19 Jul & 0.84 & 56.8 & $0.17(100)$ & 16.0 & 20.7 \\
20 Jul & 1.60 & 79.8 & $0.08(87.3)$ & 7.6 & 4.9 \\
21 Jul & 0.40 & 33.0 & $0.14(72.0)$ & 13.3 & 35.8 \\
22 Jul & 2.00 & 86.5 & $0.18(76.5)$ & 16.4 & 9.0 \\
23 Jul & 0.90 & 59.3 & $0.12(83.6)$ & 11.5 & 13.6 \\
24 Jul & 3.70 & 97.5 & $0.11(100)$ & 10.3 & 3.0 \\
Mean & 1.48 & 69.6 & $0.23(73.5)$ & 19.4 & 21.1 \\
$\mathrm{SD}$ & 0.96 & 19.2 & $0.18(28.7)$ & 13.3 & 17.2 \\
\hline
\end{tabular}

to 0.65 , equivalent to 7.6 to $47.9 \%$ $20 \mathrm{~h}^{-1}$. Medusae were responsible for most of the predation (72 to $100 \%$ ) except at Stn 4 on 7 July $(26 \%)$. The percentages of total estimated egg mortality $\left(Z_{\mathrm{E} r}\right)$ that were caused by predation ranged from 3 to $52 \%$ (Table 8, Fig. 5A).

Medusae consumed large percentages of the bay anchovy larvae each day (Table 9), but we did not detect predation on larvae by ctenophores. The daily larval predation mortality $\left(Z_{\mathrm{LM}} \mathrm{d}^{-1}\right)$ ranged from 0.11 to 0.79 (10.3 to $54.5 \% \mathrm{~d}^{-1}$; Table 9 ). The calculated percentages of total estimated larval mortality $\left(Z_{\mathrm{LT}}\right)$ that were caused by predation were 11.1 to $192.7 \%$ (Table 9, Fig. 5B).

\section{DISCUSSION}

\section{Gelatinous zooplankton biovolumes, densities, and sizes}

Population sizes of gelatinous predators are critical in determining the importance of their impacts on ichthyoplankton and zooplankton (e.g. Purcell \& Grover 1990, Purcell 1992). Medusa and ctenophore biovolumes in the mesohaline region of Chesapeake Bay (Stns 4 to 7) during this study were 1 to $7 \mathrm{ml} \mathrm{m}^{-3}$ and 2 to $47 \mathrm{ml} \mathrm{m}^{-3}$, respectively, which are typical of this region of the bay in July. In the York and LaFayette River tributaries and off Calvert Cliffs in Chesapeake Bay, combined predator volumes were 10 to $50 \mathrm{ml} \mathrm{m}^{-3}$ (Burrell \& Van Engel 1976, Feigenbaum \& Kelly 1984, Olson 1987). Data from a transect $\left(38^{\circ} 33^{\prime} \mathrm{N}\right)$ just north of Stn 7

Ctenophores contained $\leq 3$ bay anchovy eggs, and no larvae (Table 4). Of 75 ctenophores, 51 contained no eggs. There were no significant regression relationships between the number of eggs in the ctenophore gut contents and egg density or ctenophore size, probably due to the low number of ctenophores with eggs and the low numbers of eggs per ctenophore.

Predation by medusae and ctenophores removed substantial proportions of bay anchovy eggs daily (Table 8 ). On the different dates, the combined daily egg predation mortality $\left(Z_{\text {EP }} 20 \mathrm{~h}^{-1}\right)$ ranged from 0.08 also show comparable predator volumes, with maximum biovolumes of 72 to $90 \mathrm{ml}$ ctenophores $\mathrm{m}^{-3}$ in early August 1987 and 1988 (Purcell et al. 1994). The relative importance of medusae and ctenophores differs between years and across the bay, with medusae having the greatest predation effects on the bay flanks (Purcell et al. 1994).

Surprisingly, the biovolumes of medusae and ctenophores on each day (Fig. 2) were not obviously related to the total estimated mortality rates of eggs or larvae (Fig. 5A, B). There was a significant correlation be- 

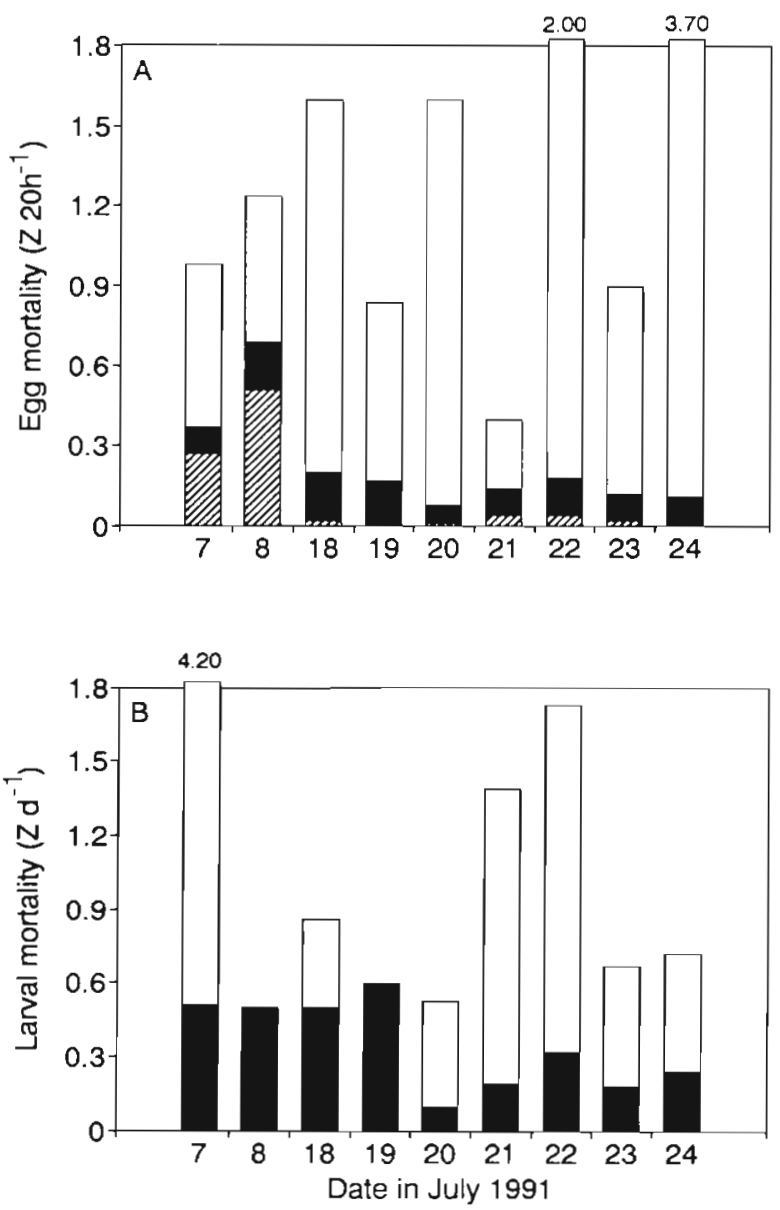

Fig. 5. Anchoa mitchilli. Total estimated daily mortality (open bars), and the proportions of mortality due to medusae (solid bars) and ctenophores (hatched bars) for (A) eggs and

(B) larvae

Table 9. Anchoa mitchilli. Total daily larval mortality, percentage of larvae consumed daily by medusae, and percentage of larval mortality due to medusa predation on sampling dates in July 1991. Total larval mortality calculated from Dorsey (1993)

\begin{tabular}{|c|c|c|c|c|c|}
\hline \multirow[t]{2}{*}{$\begin{array}{l}\text { Date } \\
(1991)\end{array}$} & \multicolumn{2}{|c|}{$\begin{array}{c}\text { Total larval } \\
\text { mortality }\end{array}$} & \multicolumn{2}{|c|}{$\begin{array}{c}\text { Larvae } \\
\text { consumed }\end{array}$} & \multirow{2}{*}{$\begin{array}{c}\text { Larval mortality } \\
\text { due to predation } \\
\qquad(\%)\end{array}$} \\
\hline & $Z_{\mathrm{LT}} \mathrm{d}^{-1}$ & $\% d^{-1}$ & $Z_{L M} d^{-1}$ & $\% d^{-1}$ & \\
\hline $7 \mathrm{Jul}$ & 4.25 & 98.6 & 0.47 & 37.7 & 11.1 \\
\hline $8 \mathrm{Jul}$ & 0.41 & 33.5 & 0.79 & 54.5 & 192.7 \\
\hline $18 \mathrm{Jul}$ & 0.86 & 57.8 & 0.33 & 28.0 & 38.4 \\
\hline $19 \mathrm{Jul}$ & 0.53 & 41.0 & 0.59 & 44.7 & 111.3 \\
\hline $20 \mathrm{Jul}$ & 0.53 & 41.0 & 0.11 & 10.3 & 20.8 \\
\hline $21 \mathrm{Jul}$ & 1.39 & 75.1 & 0.20 & 18.3 & 14.4 \\
\hline $22 \mathrm{Jul}$ & 1.73 & 82.2 & 0.34 & 29.2 & 19.7 \\
\hline $23 \mathrm{Jul}$ & 0.67 & 48.9 & 0.19 & 17.1 & 28.4 \\
\hline $24 \mathrm{Jul}$ & 0.72 & 51.3 & 0.24 & 21.5 & \\
\hline Mean & 1.23 & 58.8 & 0.36 & 29.0 & $40.7^{d}$ \\
\hline $\mathrm{SD}$ & 1.21 & 21.9 & 0.22 & 14.3 & $34.7^{\mathrm{d}}$ \\
\hline
\end{tabular}

tween medusa biovolumes and estimated total daily larval mortality (positive, $\mathrm{r}^{2}=0.59, \mathrm{p}=0.015$ ). In concurrent sampling, Dorsey (1993) also found a significant correlation only between medusa biovolume and estimated total daily larval mortality (positive, $\mathrm{p}<$ 0.01 ). Houde et al. (in press) found no significant correlations between egg and larval mortality rates and the numbers or biovolumes of ctenophores and medusae in $3.2 \mathrm{~m}^{3}$ mesocosms that were deployed each day during the present study. They speculated that variability in initial numbers of ichthyoplankton and predators in a small number of mesocosms may partly explain why they were unable to quantify effects of predators on egg and larval mortality.

The importance of predation also is determined by the spatial overlap of predator and prey populations (e.g. Frank \& Leggett 1985). We found that significantly more medusae and ctenophores occurred above the pycnocline than below it. Bay anchovy eggs and larvae also were far more abundant above the pycnocline than below it in Chesapeake Bay (MacGregor 1994). Therefore, both predators and prey were concentrated above the pycnocline in the mesohaline region of Chesapeake Bay.

However, gelatinous predators and bay anchovy eggs and larvae did not co-occur in the southern Chesapeake Bay during 3 to 5 July 1991 (Stns 1 to 3). Estimated total mortality rates of bay anchovy eggs and larvae were lower at these stations $(0.041 \pm$ $0.058 \mathrm{~h}^{-1}$ ), where no medusae or ctenophores were collected during intensive sampling, than at the mesohaline stations $\left(0.074 \pm 0.048 \mathrm{~h}^{-1}\right.$; Dorsey 1993). Houde (unpubl. results) found ctenophores in June 1993 but not in July, and no medusae occurred in either month in the southern bay. However, Govoni \& Olney (1991) reported densities of Mnemiopsis leidyi up to $227 \mathrm{~m}^{-3}$ during 11 to 21 June 1985 near the mouth of Chesapeake Bay. Nevertheless, little or no predation mortality was due to gelatinous species during our sampling in 1991 in the southern bay.

\section{Diet and prey selection of medusae}

During the spawning season of bay anchovy, its eggs and larvae were important components of the diet of Chrysaora quinquecirrha medusae. Eggs and newly hatched larvae average $1.8 \mu \mathrm{g}$ nitrogen and $1.5 \mu \mathrm{g}$ nitrogen, respectively (Tucker 1989). Eggs and larvae contributed, on average, 
$71 \mu \mathrm{g} \mathrm{N}$ medusa ${ }^{-1} \mathrm{~d}^{-1}$ to ingestion. Eggs were most important, contributing $80 \%$ of the bay anchovy nitrogen ingested. Nitrogen from zooplankton ingested was calculated as in Purcell (1992), and averaged $331 \mu \mathrm{g} \mathrm{N}$ medusa ${ }^{-1} \mathrm{~d}^{-1}$ Therefore, ichthyoplankton contributed $18 \%$ of the nitrogen from zooplankton and ichthyoplankton in the diet $\left(402 \mu \mathrm{g} \mathrm{N}\right.$ medusa $\left.{ }^{-1} \mathrm{~d}^{-1}\right)$, which exceeds the daily minimum nitrogen demand, as estimated by ammonium excretion, for medusae up to about $60 \mathrm{~mm}$ in diameter (Purcell 1992). Ctenophores also are consumed by the medusae, and are another source of nitrogen that could exceed these other sources in the diet (one $70 \mathrm{~mm}$ ctenophore $=3150 \mu \mathrm{g}$ $\mathrm{N}_{i}$ Nemazie et al. 1993). However, medusa ingestion rates of ctenophores could not be determined from gut content analyses

Chrysaora quinquecirrha medusae were found to show positive selection for eggs and larvae of bay anchovy. Positive selection for fish eggs and larvae has been shown previously for the scyphomedusae Cyanea capillata and Pseudorhiza haeckeli (in Fancett \& Jenkins 1988), hydromedusae Aequorea victoria (in Purcell 1989), and cystonect siphonophores (in Purcell 1981, 1984). Fish eggs and yolk-sac larvae may be positively selected by the medusae because ichthyoplankton is large relative to most other zooplankton (increasing probability of encounter), and they have little or no escape ability.

\section{Digestion times}

Data for Chrysaora quinquecirrha showed that bay anchovy eggs and zooplankton prey had similar digestion times (mean $3.9 \mathrm{~h}$ for eggs, $3.5 \mathrm{~h}$ for copepods in Purcell 1992). We saw no significant effect of egg number (9 to 52) on digestion time. The number of copepods ingested ( 3 to 631) also did not affect digestion times of C. quinquecirrha significantly (Purcell 1992). However, some medusae in situ contained as many as 1500 eggs. Therefore, in some samples, digestion times for eggs may have been underestimated, and selection and feeding rates overestimated. In contrast, bay anchovy larvae probably were under-represented in the gut contents because of their short digestion time $(1.1 \mathrm{~h})$, resulting in low estimates of selection and feeding rates. Medusae in 2 samples had many larvae in their gut contents (up to 71 ), while in the digestion experiments only 1 to 9 larvae were used. It was not possible to measure digestion times for high numbers of fish eggs and larvae. For ctenophores, the digestion times of 10 to $15 \mathrm{~min}$ for bay anchovy eggs reported in Monteleone \& Duguay (1988) are inaccurate because they divided the total times by the numbers of eggs ingested (Monteleone 1988).

\section{Feeding rates and predation effects}

Clearance rates of bay anchovy eggs and larvae by Chrysaora quinquecirrha were similar in situ and in mesocosms, and similar to those calculated for other scyphomedusae (Table 10). These clearance rates of eggs and larvae were higher than rates measured in containers $<1 \mathrm{~m}^{3}$ volume (Table 10 ). Clearance rates of fish larvae by Aurelia aurita doubled as container volume increased from 0.26 to $6.35 \mathrm{~m}^{3}$ (de Lafontaine \& Leggett 1987). Because clearance rates also increase with medusa size, we have presented data for medusae with similar diameters (Table 10). Clearance rates of $C$. quinquecirrha on copepods were much lower $\left(16 \mathrm{l} \mathrm{d}^{-1}\right.$ medusa $^{-1}$ for medusae $40 \mathrm{~mm}$ diameter), and cannot be compared to clearance rates on fish eggs or larvae due to the different characteristics of these prey (Purcell 1992).

Predation effects by Chrysaora quinquecirrha medusae were 7 to $17 \% 20 \mathrm{~h}^{-1}$ on eggs and 10 to $54 \%$ $\mathrm{d}^{-1}$ on larvae in the present study. These rates are much higher than estimates of predation by other species of scyphomedusae $\left(<5 \% \mathrm{~d}^{-1}\right.$, Table 10$)$, probably because of the high abundances of scyphomedusae in the mesohaline Chesapeake Bay. The combined predation effects by $C$. quinquecirrha and Mnemiopsis leidyi on bay anchovy eggs and larvae in the mesohaline Chesapeake Bay ( 8 to $54 \% \mathrm{~d}^{-1}$ ) were similar to those estimated using clearance rates of large specimens in $3.2 \mathrm{~m}^{3}$ mesocosms and previously published biovolumes of the predators (20 to $40 \% \mathrm{~d}^{-1}$; Cowan \& Houde 1993).

The clearance rates of eggs by Mnemiopsis leidyi were similar in this study and all others, except for clearance rates in $3.2 \mathrm{~m}^{3}$ mesocosms, which were about 3 times higher (Table 10). Monteleone \& Duguay (1988) found that clearance rates of eggs increased with increasing container volume (15 to $200 \mathrm{l})$ and ctenophore size. Monteleone \& Duguay (1988) and Cowan \& Houde (1993) found substantial clearance of larvae in containers (Table 10 ). We did not find any fish larvae in the gut contents of $M$. leidyi, which may be because of rapid digestion by the ctenophores, and because larval densities in situ were low relative to egg densities.

We calculated that Mnemiopsis leidyi consumed from 0 to $36 \% \mathrm{~d}^{-1}$ of the bay anchovy eggs, and we found no predation on larvae. From maximum clearance rates measured in $200 \mathrm{l}$ containers, Monteleone \& Duguay (1988) predicted greater effects of $M$. leidyi, estimating that they could consume 10 to $65 \%$ of the bay anchovy eggs in Great South Bay, New York, and 11 to $55 \%$ of the yolk-sac larvae. Govoni \& Olney (1991) used maximum clearance rates $\left(168 \mathrm{l} \mathrm{d}^{-1}\right)$ from Monteleone \& Duguay (1988) and field densities of $M$. 
Table 10. Clearance rates and predation effects in situ on fish eggs and larvae by scyphomedusae and ctenophores. Predator size given as diameter or volume. Volumes listed under 'Condition' are for mesocosms in the field. na: not available

\begin{tabular}{|c|c|c|c|c|c|}
\hline $\begin{array}{l}\text { Predator species } \\
\text { Predator size }\end{array}$ & Condition & Prey type & $\begin{array}{c}\text { Clearance rates } \\
\left(\mathrm{l} \mathrm{d}^{-1} \text { predator }^{-1}\right)\end{array}$ & $\begin{array}{l}\text { Prey consumed } \\
\qquad\left(\% d^{-1}\right)\end{array}$ & Source \\
\hline \multicolumn{6}{|c|}{ Chrysaora quinquecirrha } \\
\hline $40 \mathrm{~mm}$ & Field & Eggs & $1318 \pm 707^{\circ}$ & $9-50^{c}$ & This study ( 3 samples) \\
\hline $55 \mathrm{~mm}$ & Field & Eggs & $2498 \pm 1120^{d}$ & $9-50^{c}$ & This study (4 samples) \\
\hline $100 \mathrm{~mm}^{\mathrm{a}}$ & $3.2 \mathrm{~m}^{3}$ & Eggs & 2983 & $20-40^{c, d}$ & Cowan \& Houde (1993) \\
\hline $90 \mathrm{~mm}^{\mathrm{d}}$ & Lab., $750 \mathrm{l}$ & Eggs & $1359 \pm 31$ & $20-40^{c \cdot d}$ & Cowan \& Houde (1993) \\
\hline $40 \mathrm{~mm}$ & Field & Larvae & $714^{d}$ & $10-45^{c}$ & This study (2 samples) \\
\hline $55 \mathrm{~mm}$ & Field & Larvae & $3703 \pm 3765^{a}$ & $10-45^{c}$ & This study (4 samples) \\
\hline $75 \mathrm{~mm}^{\mathrm{d}}$ & $3.2 \mathrm{~m}^{3}$ & Larvae & 600 & $20-40^{c, d}$ & Cowan \& Houde (1993) \\
\hline \multicolumn{6}{|c|}{ Stomolophus meleagris } \\
\hline $55 \mathrm{~mm}$ & Field & Eggs & 3120 & na & Larson (1991) \\
\hline \multicolumn{6}{|l|}{ Cyanea capillata } \\
\hline $40 \mathrm{~mm}$ & Lab., 251 & Eggs \& larvae & 140 & $0.1-2.4$ & Fancett \& Jenkins (1988) \\
\hline \multicolumn{6}{|c|}{ Pseudorhiza haeckeli } \\
\hline $40 \mathrm{~mm}$ & Lab., 25 I & Eggs \& larvae & 400 & $0.1-3.8$ & Fancett \& Jenkins (1988) \\
\hline \multicolumn{6}{|l|}{ Aurelia aurita } \\
\hline $6-50 \mathrm{~mm}$ & Field & Larvae & na & $2.6-4.4$ & Möller (1980) \\
\hline $40-80 \mathrm{~mm}$ & $6.3 \mathrm{~m}^{3}$ & Larvae & 526 & na & de Lafontaine \& Leggett (1987) \\
\hline $10-85 \mathrm{~mm}$ & $5 \mathrm{~m}^{3}$ & Larvae & mean $182, \max .1347$ & na & Gamble \& Hay (1989) \\
\hline \multicolumn{6}{|c|}{ Mnemiopsis leidyj } \\
\hline $40 \mathrm{ml}^{\mathrm{b}}$ & Field & Eggs & $128 \pm 58^{a}$ & $0-38^{c}$ & This study (8 samples) \\
\hline $17 \mathrm{ml}$ & $3.2 \mathrm{~m}^{3}$ & Eggs & 366 & $20-40^{c d}$ & Cowan \& Houde (1993) \\
\hline $3 \mathrm{ml}$ & $2.2 \mathrm{~m}^{3}$ & Eggs & $50 \pm 46$ & na & Cowan \& Houde (1992) \\
\hline $15 \mathrm{ml}$ & Lab., 7501 & Eggs & 110 & $20-40^{c d}$ & Cowan \& Houde (1993) \\
\hline $13 \mathrm{ml}^{\mathrm{b}}$ & Lab., 2001 & Eggs & $60-170$ & $10-65^{c}$ & Monteleone \& Duguay (1988) \\
\hline $21 \mathrm{ml}$ & $3.2 \mathrm{~m}^{3}$ & Larvae & $172 \pm 26$ & $20-40^{c d}$ & Cowan \& Houde $(1993$ \\
\hline $4 \mathrm{ml}^{\mathrm{b}}$ & Lab., 151 & Larvae & $20-66^{b}$ & $11-55^{c}$ & Montelone \& Duguay (1988) \\
\hline
\end{tabular}

leidyi, and estimated that ctenophores in surface waters might have consumed 0.1 to 14.7 and 21 to 174 eggs $\mathrm{m}^{-3} \mathrm{~d}^{-1}$ at 2 stations at the mouth of Chesapeake Bay. These estimates are comparable with our range in the mesohaline region of 10 to 79 eggs $\mathrm{m}^{-3} \mathrm{~d}^{-1}$.

Although Houde et al. (in press) were unable to show statistically significant relationships between gelatinous predator numbers or biovolumes and the estimated mortality rates of bay anchovy eggs and larvae in drifting mesocosms deployed during our study, effects of predators were observed: (1) Hourly egg mortality on days when manipulated mesocosms had 2 medusae added (20 to 23 July) was higher $(0.096 \pm$ 0.028 ; Houde et al. in press) than mortality in situ on those dates $(0.061 \pm 0.018$; Dorsey 1993). Hourly egg mortality in unmanipulated mesocosms ( 7 to 23 July, $0.070 \pm 0.014)$ compared reasonably well with mortality in situ on those dates $(0.060 \pm 0.009)$. The predation rates determined from gut contents (Table 8 ) could have accounted for 15 to $65 \%(23 \pm 17 \%)$ of the egg mortality in the unmanipulated mesocosms. (2) Hourly larval mortality in the manipulated mesocosms with 2 added medusae $(0.065 \pm 0.023$; Houde et al. in press $)$ was higher than in situ on 20 to 23 July $(0.045 \pm 0.012$; Dorsey 1993). Hourly larval mortality may have been lower in the unmanipulated mesocosms than in situ on 7 to 23 July $(0.041 \pm 0.021$. Houde et al. in press; 0.060 \pm 0.009 , Dorsey 1993). The in situ predation rates (Table 9) could have accounted for $42 \pm 37 \%$ of the larval mortality in the unmanipulated mesocosms.

The multiple regression analyses used to predict the numbers of eggs and larvae in medusae had high percentages of unexplained variation. Only $33.5 \%$ of the variation in egg numbers in gut contents was explained by egg density and medusa size, and only $22.6 \%$ of the variation in larval numbers was explained by larval density and medusa size. Even though we attempted to collect samples concurrently for egg and larval mortality, predator densities, and predator feeding, the various samples could not be 
taken from the same small volume of water. Smallscale patchiness of predators and prey may have caused much of the unexplained variation.

Nevertheless, the multiple regression equations were significant, and we believe that they provided better estimates of medusa predation on bay anchovy eggs and larvae than did gut contents alone (as in Purcell et al. 1993) for 2 reasons. First, mean medusa sizes collected for gut content analysis were larger than sizes in the general population. Consequently, predation rates calculated directly from gut contents were greater. Second, the regression model allowed us to estimate predation at sampling times when gut samples were missing.

Comparison of these 2 approaches showed that daily egg mortality rates by medusae ( $Z_{E M}$; Table 8$)$ obtained by predicting egg predation from the multiple regression (Table 6) were lower on 6 days when many eggs were found in the gut contents (difference $=0.41 \pm 0.16 \mathrm{~d}^{-1}$ ), and were slightly higher on 3 days when the lowest numbers of eggs were in the guts (difference $=0.01 \pm 0.01 \mathrm{~d}^{-1}$ ) than those calculated directly from gut contents on each day (in Purcell et al. 1993). In contrast, daily larval mortality rates due to medusae $\left(Z_{L, M}\right.$, Table 9$)$ obtained from the multiple regression (Table 7) were higher on 6 days when few larvae were found in the gut samples (difference = $0.25 \pm 0.18 \mathrm{~d}^{-1}$ ), and were lower on 3 days when many larvae were in the guts (difference $=0.92 \pm 0.80$ $\mathrm{d}^{-1}$ ) than those calculated directly from gut contents (in Purcell et al. 1993).

Other predators in addition to the scyphomedusan Chrysaora quinquecirrha and the ctenophore Mnemiopsis leidyi would have contributed to bay anchovy egg and larva mortality. The hydromedusan Nemopsis bachei was present in low numbers $\left(0.2 \pm 0.5 \mathrm{~m}^{3}\right.$ above the pycnocline) during our sampling. Clearance rates of $N$. bachei feeding on black drum eggs averaged $61 \mathrm{l} \mathrm{d}^{-1}$ medusa $^{-1}$ in $2.2 \mathrm{~m}^{3}$ mesocosms during May 1990 near the mouth of Chesapeake Bay (Cowan et al. 1992). If we apply this clearance rate to densities of $N$. bachei at our stations, then this species accounted for 0 to $9 \% \mathrm{~d}^{-1}$ (mean $1.4 \pm 2.7 \% \mathrm{~d}^{-1}$ ) of the bay anchovy eggs consumed. The importance of egg cannibalism by adult bay anchovy is not fully known, but they are thought not to be major consumers of eggs based on stomach analysis of specimens from Chesapeake Bay (Klebasko 1991). However, experiments in mesocosms indicated that they did consume eggs (Cowan \& Houde 1993). We believe that scyphomedusae, which had high feeding rates but low abundances, and ctenophores, which had low feeding rates but high abundances, were important predators of bay anchovy eggs and larvae in the mesohaline region of Chesapeake Bay.
Acknowledgements. This research was funded by NSF grants OCE-8701304 and OCE-9203307 to E. D. Houde and NOAA grant 90NA90AA-D-SG063 to the University of Maryland Sea Grant College. We thank C. T. Baier and K. B. Heidelberg for analysis of the gut content samples, and F. P. Cresswell and N. J. Olesen for assisting with the digestion experiments. We also thank all those who assisted in the field, including the Captain and crew of the RV 'Cape Henlopen' UMCEES Contribution No. 2543

\section{LITERATURE CITED}

Alvarino, A. (1985). Predation in the plankton realm: mainly with reference to fish larvae. Invest. Mar CICIMAR 2: $1-122$

Arai, M. N. (1988). Interactions of fish and pelagic coelenterates. Can. J. Zool 66: 1913-1927

Bailey, K. M., Houde, E. D. (1989). Predation on eggs and larvae of marine fishes and the recruitment problem. Adv. mar. Biol. 26: 1-83

Baird, D., Ulanowicz, R. E. (1989). The seasonal dynamics of the Chesapeake Bay ecosystem. Ecol. Monogr. 59: $329-364$

Burrell, V G. Jr, Van Engel, W. A. (1976). Predation by and distribution of a ctenophore Mnemiopsis leidyi A. Agassiz, in the York River estuary. Estuar coast. mar. Sci. 4: $235-242$

Cowan, J. H. Jr, Houde, E D. (1992). Size-dependent predation on marine fish larvae by ctenophores, scyphomedusae, and planktivorous fish. Fish. Oceanogr. 1: 113-126

Cowan, J. H. Jr, Houde, E. D. (1993). Relative predation potentials of scyphomedusae, ctenophores and planktivorous fish on ichthyoplankton in Chesapeake Bay. Mar. Ecol. Prog. Ser. 95: 55-65

Cowan, J. H. Jr, Birdsong, R. S., Houde, E. D., Priest, J. S., Sharp, W. C., Mateja, G. B. (1992). Enclosure experiments on survival and growth of black drum eggs and larvae in lower Chesapeake Bay. Estuaries 15: 392-402

Dalton, P. (1987). Ecology of Anchoa mitchilli eggs and larvae in the mid-Chesapeake Bay. M.Sc thesis, Univ. of Maryland, College Park

de Lafontaine, Y., Leggett, C. (1987). Effect of container size on estimates of mortality and predation rates in experiments with macrozooplankton and larval fish. Can. J. Fish. Aquat. Sci. 44: 1534-1543

Dorsey, S. E. (1993). Daily variability in morality of bay anchovy (Anchoa mitchilli) eggs and yolk-sac larvae in Chesapeake Bay, USA. M.Sc. thesis, Univ. of Maryland, College Park

Dovel, W. L. (1971). Fish eggs and larvae of the upper Chesapeake Bay. Spec. Rep. No. 4, Natural Resources Institute, Univ. of Maryland

Fancett, M. S. (1988). Diet and prey selectivity of scyphomedusae from Port Phillip Bay, Australia. Mar. Biol. 98: 503-509

Fancett, M. S., Jenkins, G. P. (1988). Predatory impact of scyphomedusae on ichthyoplankton and other zooplankton in Port Phillip Bay. J. exp. mar. Biol. Ecol. 116: 63-77

Feigenbaum, D., Kelly, M. (1984). Changes in the lower Chesapeake Bay food chain in presence of the sea nettle Chrysaora quinquecirrha (Scyphomedusa). Mar. Ecol. Prog. Ser. 19: 39-47

Frank, K. T., Leggett, W. C. (1985). Reciprocal oscillations in densities of larval fish and potential predators: a reflection of present or past predation? Can. J. Fish. Aquat. Sci. 42: $1841-1849$ 
Gamble, J. C., Hay, S. J. (1989). Predation by the scyphomecusan Aurelua aunta on herring larvae in large enclosures: effects of predator size and prey starvation. Rapp. P.-v. Reun. Cons. int. Explor. Mer 191: 366-375

Govoni, J. J., Olney J. E. (1991). Potential predation on fish eggs by the lobate ctenophore Mnemiopsis leidyi within and outside the Chesapeake Bay plume. Fish. Bull. U.S. 89: $181-186$

Houde, E. D., Gamble, J. C., Dorsey, S. E., Cowan, J. H. Jr (in press). Drifting mesocosms: the influence of gelatinous zooplankton on mortality of bay anchovy Anchoa mitchilli egg and yolk-sac larvae. ICES J. mar. Sci. 51

Houde, E. D., Zastrow, C. E. (1991). Bay anchovy. In: Funderburk, S. L., Mihursky, J. A., Jordan, S. J., Riley, D. (eds.) Habitat requirements for Chesapeake Bay living resources, 2nd edn. Living Resources Subcommittee, Chesapeake Bay Program, Annapolis, MD, p. 8-1 to 8-14

Klebasko, M. J. (1991). Feeding ecology and daily ration of bay anchovy (Anchoa mitchilli) in the mid-Chesapeake Bay. M.Sc. thesis, Univ. Maryland, College Park

Kremer, P., Nixon, S. (1976). Distribution and abundance of the ctenophore Mnemiopsis leidyi in Narragansett Bay Estuar. coast. mar. Sci. 4:627-639

Larson, R. J. (1991). Diet, prey selection, and daily ration of Stomolophus meleagris, a filter-feeding scyphomedusa from the NE Gulf of Mexico. Estuar. coast. Shelf Sci. 32: 511-525

Luo, J., Musick, J. (1991). Reproductive biology of the bay anchovy in Chesapeake Bay. Trans. Am. Fish. Soc. 120: $701-710$

MacGregor, J. M. (1994). Onshore-offshore pattern and variability in distribution and abundance of bay anchovy, Anchoa mitchilli, eggs and larvae in Chesapeake Bay. M.Sc. thesis, Univ. of Maryland, College Park

Möller, H. (1980). Scyphomedusae as predators and food competitors as larval fish. Meeresforsch. 28: 90-100

Monteleone, D. M. (1988). Trophic interactions of ichthyoplankton in Great South Bay, New York. Ph.D. dissertation, State Univ. of New York, Stony Brook

Monteleone, D. M., Duguay, L. E. (1988). Laboratory studies of predation by the ctenophore Mnemiopsis leidyi on the early stages in the life history of the bay anchovy, Anchoa mitchilli. J. Plankton Res. 10: 359-372

Nemazie, D. A., Purcell, J. E., Glibert, P. M. (1993). Ammonium excretion by gelatinous zooplankton and their contribution to the ammonium requirements of microplankton in Chesapeake Bay. Mar. Biol. 116: 451-458

Olney, J. E. (1983). Eggs and early larvae of the bay anchovy, Anchoa mitchilli, and the weakfish. Cynoscion regalis, in

This article was presented by K. Sherman (Senior Editorial Advisor), Narragansett, Rhode Island, USA lower Chesapeake Bay with notes on associated ichthyoplankton. Estuaries 6: 20-35

Olson, M. M. (1987). Zooplankton. In: Heck, K. L. Jr (ed.) Ecological studies in the middle reach of Chesapeake Bay. Springer Verlag, Berlin, p. 38-81

Pearre, S. Jr (1982). Estimating prey preference by predators: uses of various indices, and a proposal of another based on $\chi^{2}$ Can. J. Fish. Aquat. Sci. 39: 914-923

Purcell, J. E. (1981). Feeding ecology of Rhizophysa eysenhardti, a siphonophore predator of fish larvae. Limnol. Oceanogr. 26: $424-432$

Purcell, J. E. (1984). Predation on fish larvae by Physalia physalis, the Portuguese man of war. Mar. Ecol. Prog. Ser. 19: $189-191$

Purcell, J. E. (1985). Predation on fish eggs and larvae by pelagic cnidarians and ctenophores. Bull. mar. Sci. 37 $739-755$

Purcell, J. E. (1988). Quantification of Mnemiopsis leidyi (Ctenophora, Lobata) from formalin-preserved plankton samples. Mar. Ecol. Prog. Ser. 45: 197-200

Purcell, J. E. (1989). Predation on fish larvae and eggs by the hydromedusa (Aequorea victoria) at a herring spawning ground in British Columbia. Can. J. Fish. Aquat. Sci. 46: $1415-1427$

Purcell, J. E. (1992). Effects of predation by the scyphomedusan Chrysaora quinquecirrha on zooplankton populations in Chesapeake Bay, USA. Mar. Ecol. Prog. Ser. 87: 65-76

Purcell, J. E., Grover, J. J. (1990). Predation and food Iimitation as causes of mortality in larval herring at a spawning ground in British Columbia. Mar. Ecol. Prog. Ser. 59: 55-61

Purcell, J. E., Nemazie, D. A., Dorsey, S. E., Houde, E. D., Gamble, J. C. (1993). In situ predation rates on bay anchovy (Anchoa mitchilli) eggs and larvae by scyphomedusae (Chrysaora qunquecirrha) and ctenophores (Mnemiopsis leidyil in Chesapeake Bay. Comm. Meet. int. Coun. Explor. Sea C.M.-ICES/L: 42

Purcell, J E., White, J. R., Roman M. R. (1994). Predation by gelatinous zooplankton and resource limitation as potential controls of Acartia tonsa copepod populations in Chesapeake Bay. Limnol. Oceanogr. 39: 263-278

Tucker, J. W Jr (1989). Energy utilization in bay anchovy, Anchoa mitchelli, and black sea bass, Centropristis striata striata, eggs and larvae. Fish. Bull. U.S. 87: 279-293

Zastrow, C. E., Houde, E. D., Morin, L. G. (1991). Spawning, fecundity, hatch-date frequency, and young-of-the-year growth of bay anchovy Anchoa mitchilli in mid-Chesapeake Bay. Mar. Ecol. Prog. Ser. 73: 161-171

Manuscript first received: February 10, 1994

Revised version accepted: July 11, 1994 